\title{
MODERN RESOURCES OF CELIAC DISEASE TREATMENT EFFECTIVENESS IMPROVEMENT
}

\author{
Gubska O.Yu. (https://orcid.org/0000-0003-1083-2903) \\ Chichula Yu.V. (https://orcid.org/0000-0003-0490-1618) \\ Sizenko A.K. \\ Kupchik L.M. (https://orcid.org/0000-0002-0851-1724) \\ Bogomolets National Medical University, Kyiv, Ukraine \\ gubskao@gmail.com
}

\begin{abstract}
Relevance. Although monotherapy with a gluten-free diet (BGD) for celiac disease is highly effective, it does not in all cases achieve complete remission of the disease. Therefore, an additional comprehensive examination of patients for the purpose of prescribing reasonable therapy is relevant.

Objective: to study the causes of persistence of clinical symptoms in patients with celiac disease who are on a gluten-free diet for 6 months.

Materials and methods. Patients with celiac disease $(n=41)$ who were on a gluten-free diet (GFD) for 6 months were studied. The average age is $35.42 \pm 0.45$ years. Group $1(n=17)$ - patients who subjectively noted a positive dynamics of treatment and with a significant improvement in general condition, but without complete clinical remission. Group $2(\mathrm{n}=24)-$ patients with unsatisfactory treatment results, no clinical effect from treatment or weak positive dynamics on the background of GFD. The study included two stages: 1) assessment of patients' compliance and their diet (through the analysis of food diaries) in order to identify disorders of gluten-free diet as the main cause of persistence of clinical symptoms; 2) identification of other causes of persistence of symptoms: exocrine pancreas insufficiency (EPI), lactase deficiency (LD) and the syndrome of increase bacterial growth (SIBR). A C13 triglyceride breath test (IRIS analyzer) was performed to diagnose EPI. To diagnose LD and SIBR in the small intestine, hydrogen breath tests (Micro H2-meter analyzer) were used - a test with lactose and D-xylose, respectively. Also, the titer of antibodies to tissue transglutaminase (TTG) to deaminated gliadin peptides (DPG) was determined in all patients, and their DPG/TTG ratio was calculated.

Results. The main reason for the ineffectiveness of treatment is a violation of gluten-free diet, found in $63.4 \%$ of subjects (incompletely formed mushy stool, polyfaeces, steatorrhea; recurrent abdominal pain, bloating, flatulence). Revision of food intake and elimination of sources of latent gluten from the diet of patients with celiac disease allowed to achieve complete serological remission (normalization of titers specific for celiac disease antibodies) in all patients, but complete clinical remission was achieved in only $34.6 \%$. Therefore, it is concluded that there are other causes of incomplete remission of celiac disease associated with concomitant diseases of the digestive tract. Using carbon and hydrogen breath tests, it was found that, in addition to diet, the reasons for the lack of complete remission in patients with celiac disease are EPI (19\%), SIBR in the small intestine (16\%), LD (47\%) and a combination of EPI with SIBR.

Conclusion. The inclusion of respiratory tests (C13-triglyceride, hydrogen with lactose and D-xylose) in a comprehensive examination of patients with celiac disease can significantly improve treatment outcomes and reduce the duration of clinical remission.

Key words: celiac disease, gluten-free diet, breath tests, C13-triglyceride, hydrogen with lactose and D-xylose
\end{abstract}

Relevance. Celiac disease (gluten enteropathy) is the most studied disease of the small intestine to date, the prevalence of which, according to the World Organization of Gastroenterology (OMGE), averages $1 \%$ of the general population. As you know, the only treatment for celiac disease is a gluten-free (agliadin) diet (GFD), based on the complete exclusion from the patient's diet of all foods containing the main protein of cereals (wheat, rye, barley and oats) gluten. The purpose of prescribing GFD is to stop the pathological autoimmune process in the body of a patient with celiac disease in response to the exclusion of gluten from the diet, leading to a gradual restoration of the structure of the affected mucous membrane of the small intestine, and then - the disappearance of clinical manifestations of the disease, normalization of the patient's general condition and prevention of possible complications [1]. With strict and lifelong adherence to the GFD, successfully treated patients become practically healthy.

The high efficiency of a gluten-free diet allows it to be used in monotherapy, as a method of «standard» treatment of a celiac patient and, as a rule, does not require additional inclusion of drugs in the complex therapy. Therefore, traditional attempts at starting (in combination with a gluten-free diet) prescribing drugs without appropriate medical indications (no concomitant diseases) are often unjustified. However, the existing experience in the management of patients with celiac disease indicates that not in all cases doctors are able to achieve complete remission of the disease, which prompts additional examination and, if the reasons are identified, justified therapy.

These methods, which allow to optimize the treatment of patients with gluten enteropathy, today are breath tests, 
which are widely used in the clinic of internal medicine, especially in gastroenterology. Carbon breath tests have long been known and are used to diagnose Helicobacter pylori infection (test with urea), pancreatic diseases (triglyceride, amylase), liver detoxification function (metacetin), to determine the motor-evacuation function of the stomach (octanoic), etc. $[2,3,4,5]$. The use of hydrogen breath tests became available somewhat later, but they also took their place in the diagnosis of diseases of the digestive system and are widely used to diagnose enteropathies, disaccharidase deficiency, syndrome of bacterial overgrowth in the small intestine, etc. [6].

Several attempts have been made to use hydrogen breath tests in the diagnosis of celiac disease $[7,8]$. This concerned various tests - with lactulose, D-xylose, sorbitol, etc. an early peak in hydrogen concentration has been reported on a lactulose breath test in patients with celiac disease [9]. Described the use of a hydrogen test with D-xylose for the diagnosis of celiac disease in different age groups [10]. It has been established that this test can be used to improve screening for celiac disease (namely, to identify the consequences of atrophy of the mucous membrane of the small intestine and malabsorption) [11]. Used lactose hydrogen breath test to assess the effectiveness of celiac disease treatment [12]. The place of the hydrogen test with sorbitol has been reported both in the diagnosis of celiac disease (since the latter reflects the severity of atrophic damage to the mucous membrane of the small intestine) and in assessing the effectiveness of a gluten-free diet. According to research results, the sorbitol test reflects the stage of restoration of the structure of the mucous membrane against the background of a diet, which means that it can be recommended as a simple, affordable method for assessing the effectiveness of treatment $[13,14]$.

Objective: To study the causes of persistence of clinical symptoms in celiac patients on a gluten-free diet for 6 months.

\section{MATERIALS AND METHODS}

The study included celiac patients $(n=41)$ who had been on a gluten-free diet for 6 months. The average age of those included in the study was $35.42+0.45$ years. Women prevailed over men, accounting for a quantitative ratio of $1.6: 1$.

All patients showed positive dynamics of treatment: clinically - an improvement in the general condition, a decrease in the frequency of defecation, a tendency to normalize stool (a decrease in the frequency of bowel movements up to 3.5 times a day) in the absence of a fully formed stool (mostly mushy, a tendency to polyfecalia, steatorrhea), stabilization of body weight, increased BMI, 30\% had recurrent abdominal pain, bloating, flatulence); laboratory - normalization/reduction of antibody titers at least three times (antibodies to tissue transglutaminase (TTG), to deaminated peptides of gliadin (DPG) were determined, the DPG/TTG ratio was calculated). Thus, the persisting symptoms and the absence of complete laboratory remission (normalization of serological biomarker titers for celiac disease) did not allow the treatment results to be regarded as satisfactory and required identification of possible causes.

The included patients were divided into two groups. Group $1(n=17)$ was represented by patients who subjectively noted positive dynamics of treatment and with a significant improvement in their general condition, but without complete clinical remission. Group $2(\mathrm{n}=$ $24)$ - patients with unsatisfactory results of treatment, no clinical effect of treatment, or weak positive dynamics against the background of GFD.

The research program included two main stages:

1 - assessment of compliance of patients and their diet (through analysis of food diaries) in order to identify violations of a gluten-free diet as the main cause of persistence of clinical symptoms,

2 - identification of other causes of persistence of symptoms, namely, exocrine pancreatic insufficiency (EPI), lactase deficiency (LD) and syndrome of increase bacterial growth (SIBR) using modern carbon and hydrogen breath tests.

In order to diagnose EPI, a C13 triglyceride breath test was performed. The technique of the test is that before the test, the intake of enzyme preparations is stopped for at least 72 hours before the test. The procedure is performed in the morning on an empty stomach. The subject makes the first exhalation into a sealed, plastic bag. After that, a so-called «test» breakfast is eaten, consisting of $100 \mathrm{~g}$ of white bread, butter in terms of 0.25 $\mathrm{g} / \mathrm{kg}$ of body weight, to which C13-labeled triglycerides were previously added at the rate of $4 \mathrm{mg} / \mathrm{kg}$ of patient weight. Subsequent samples of exhaled air are collected in bags every 30 minutes for 6 hours, and then analyzed on an infrared spectrometer by IRIS by Wagner Analysen Technik (Germany).

Indicators of the maximum concentration of $\mathrm{CO}$, recorded between 150 and 210 minutes of the test, above $8 \%$, as well as the cumulative dose of released $13 \mathrm{CO} 2$ above $23 \%$ for the entire period of the test, indicate normal exocrine function of the pancreas. The maximum concentration of $13 \mathrm{CO} 2$, recorded after 210 minutes (in our study - by $271 \pm 16$ minutes), at a normal cumulative dose of $13 \mathrm{CO} 2$, indicates a latent EPI. The reduced maximum concentration of $13 \mathrm{CO} 2$, which was $4.7 \pm$ $1.4 \%$ and recorded between 150 and 210 minutes of the test, with a reduced cumulative dose of $13 \mathrm{CO} 2$ released $(18.1 \pm 5.9 \%)$, indicates a moderate EPI. A decrease in the maximum concentration to $4.8 \pm 1.3 \%$, recorded at $275 \pm 27$ minutes, with a cumulative dose of $16.7 \pm 3.5 \%$, indicates a pronounced EPI.

To diagnose lactase deficiency and SIBR in the small intestine, we used hydrogen breath tests (Micro H2-meter analyzer) - a test with lactose and D-xylose, respectively. The principle of carrying out hydrogen tests is that the hydrogen formed in the intestine by its microflora is 
included in the intestinal gases. On an empty stomach, hydrogen is formed in the large intestine in a small amount $(0.24 \mathrm{ml} / \mathrm{min}$.), After a meal, its production increases $7-20$ times $[15,16,17]$. Approximately $15 \%$ of the generated hydrogen is excreted by the lungs after being absorbed into the blood. Based on the concentration of hydrogen in the exhaled air, conclusions are drawn about its amount in the intestine $[18,19,20]$. To conduct hydrogen breath tests, we used the techniques $[19,20]$, based on the determination of the concentration of hydrogen in the air exhaled by the subject before and after a special food load. The methods for conducting hydrogen tests are of the same type. The average test duration is 2-3 hours.

Diagnosis of lactase deficiency (test with lactose) is based on the fact that lactose, entering the intestine, under the influence of bacteria, promotes the additional release of hydrogen, which, after absorption, also enters the bloodstream, and then reaches the lungs with gases and is exhaled. An increase in the concentration of lactose in the exhaled air above $20 \mathrm{ppm}$ from the initial one indicates the presence of lactose malabsorption [20]. The D-xylose breath test was used to diagnose SIBR. Interpretation of the results: the D-xylose test was considered positive when the hydrogen concentration in the patient's exhaled air increased by 20 ppm from baseline in 40-60 minutes and indicated the presence of SIBR in the small intestine.

The results were statistically processed.

\section{RESULTS AND ITS DISCUSSION}

In group 1 (patients with incomplete clinical remission), the results of serological analysis made it possible to divide patients into subgroups (Fig. 1):

$1 \mathrm{~A}(\mathrm{n}=8)$ - patients with elevated antibody titers, or seropositive patients (SPP);

1B $(n=9)$ - patients with complete normalization of serological parameters, or seronegative patients (SNP).

In subgroup 1A, the analysis of the reasons for the persistence of clinical symptoms was carried out, which indicated periodic disturbances in the diet and (or) contamination of foods with gluten (based on the analysis of food diaries), which was reflected in the absence of normalization of antibody titers against the background of the received treatment. The analysis of the diet of patients of subgroup $1 \mathrm{~B}$ testified to strict adherence to the diet, which was confirmed by the indicators of the immunological response and the complete normalization of antibody titers. Patients in subgroup $1 \mathrm{~B}$ had a high compliance, strictly followed the recommendations, however, it was not possible to achieve complete remission during the follow-up period.

In group 2 (patients with unsatisfactory treatment results), no significant clinical dynamics was observed during the observation period, both according to the results of an objective examination of patients and according to their subjective assessments. Group 2, depending on the dynamics of the immunological response to treatment, was also divided into two subgroups (Fig. 1):

$$
2 \mathrm{~A}(\mathrm{n}=18)-\text { seropositive patients; }
$$$$
2 B(n=6)-\text { seronegative patients. }
$$

As can be seen from Figure 1, the same pattern of distribution into subgroups was revealed in both groups. Namely: the dependence of treatment results on compliance, fulfillment of the requirements of the agliadin diet and, as a result, normalization of antibody titers. $26(63.4 \%)$ patients from the general group included in the study were dieting, which was determined by the leading cause of persistence of clinical symptoms. The results obtained correspond to modern ideas about the possibility of achieving a positive immunological response and restoration of antibody titers only in response to the complete elimination of gluten from the diet [1], and the glutenfree diet itself is the main decisive factor in achieving complete clinical and laboratory recovery. 15 (36.6\%) examined (subgroups $1 \mathrm{~B}$ and $2 \mathrm{~B}$ ) did not break the diet, which was confirmed by serological remission.

Therefore, the first step in correcting the persistence of clinical symptoms in patients with celiac disease of subgroups $1 \mathrm{~A}$ and $2 \mathrm{~A}(\mathrm{n}=26)$ was the actual correction of the diet based on the revision of food diaries and the search for possible sources of food contamination with gluten. As a result of the revised dietary recommendations, in 9 (34.6\%) patients, antibody titers completely normalized over 3 months of treatment, complaints disappeared, which indicated that a complete clinical and laboratory remission was achieved. In 17 (65.4\%) patients, as a result of diet correction, antibody titers also returned to normal, however, complete clinical remission was still not achieved (clinical symptoms persisted) (Fig. 2).



Fig. 1. Distribution of celiac disease patients with persistent clinical symptoms depending on the serological response to treatment (SPP - seropositive patients; SNP - seronegative patients) 


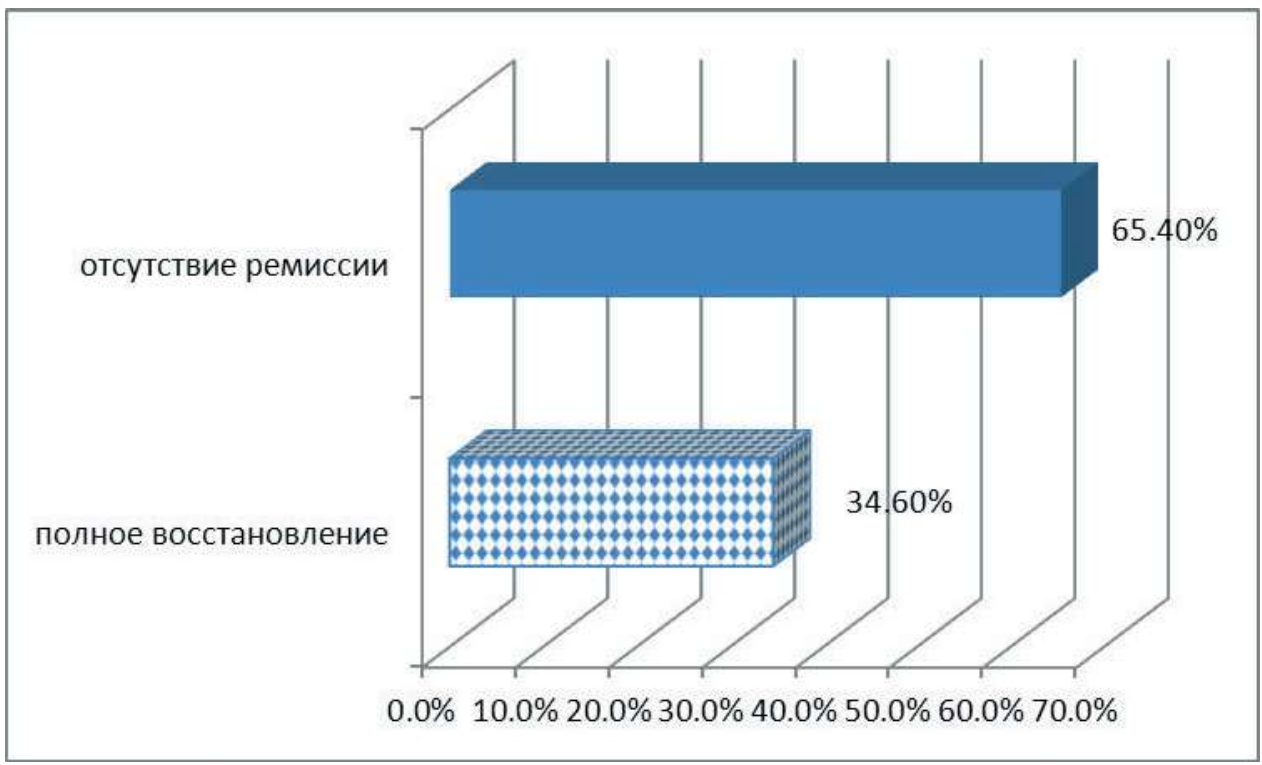

Fig. 2. Results of diet correction in celiac patients with persistent clinical symptoms $(n=26)$

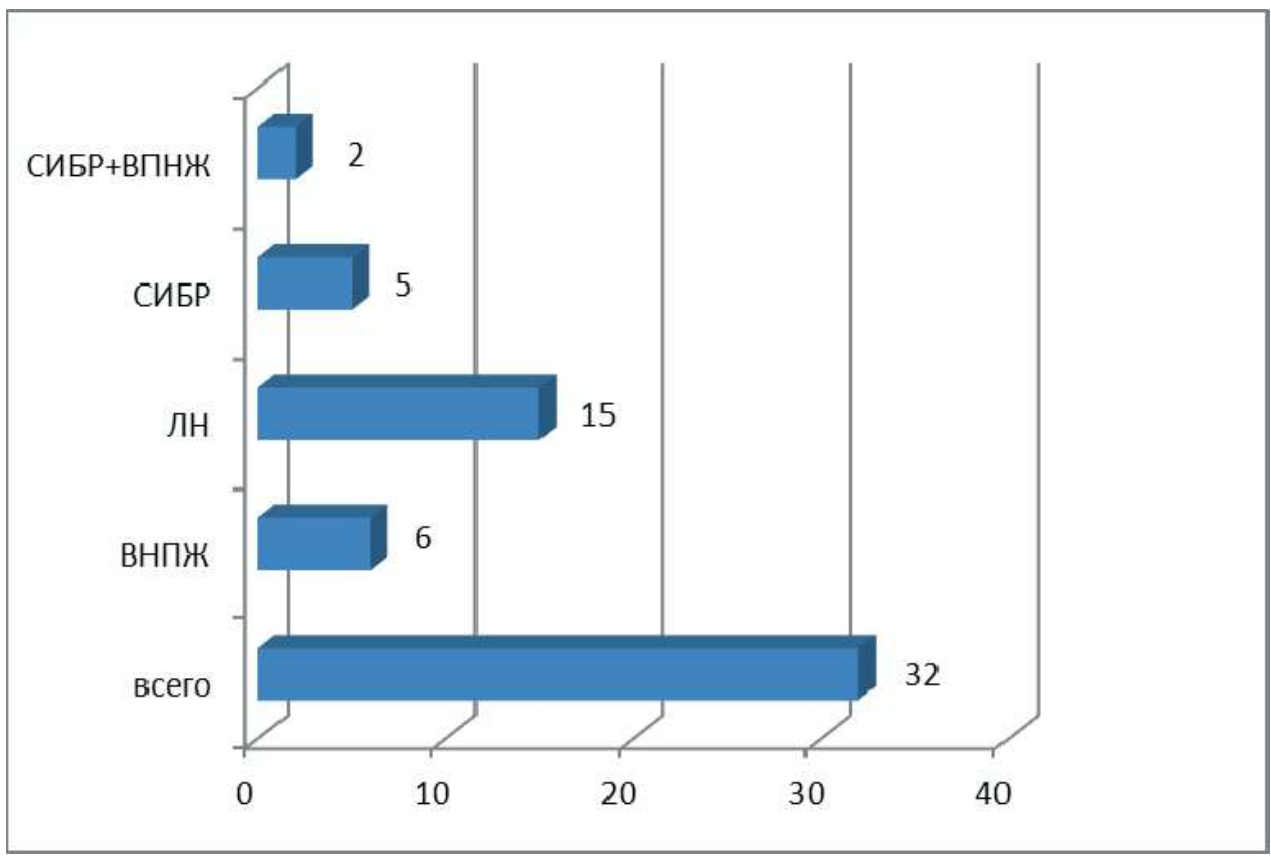

Fig. 3. The structure of the identified causes of persistence of clinical symptoms in seronegative celiac patients $(n=32)$

Thus, a violation of the diet is the first, but not the only reason for the persistence of clinical symptoms in celiac patients and requires a search for other causes. To resolve this issue, we conditionally combined patients of the first and second stages of the study, forming a group $(\mathrm{n}=32)$ of seronegative patients, which included 15 seronegative patients (subgroups $1 \mathrm{~B}$ and $2 \mathrm{~B}$ ) who did not break the diet and were identified in the first stage of the study, and 17 SNPs with persistence of symptoms, which persisted despite the correction of the gluten-free diet and restoration of antibody titers.

We made the assumption that the possible reasons for the persistence of clinical symptoms in SNP with persistence of symptoms could be exocrine pancreatic insufficiency, lactase deficiency and syndrome of bacterial overgrowth in the small intestine. Diagnosis of the above pathology was carried out using C13-triglyceride carbon and hydrogen breath tests with lactose and D-xylose, according to the methods described above.

As a result of the study, it was revealed that 6 patients (19\%) had exocrine pancreatic insufficiency, verified by the results of the $\mathrm{C} 13$-triglyceride breath test. As a result of the hydrogen test with lactose, lactase deficiency was detected in $15(47 \%)$ of the examined. SIBR was established in $5(16 \%)$ patients. In two patients of this group, a combination of severe exocrine pancreatic 
insufficiency with a syndrome of bacterial overgrowth in the small intestine was revealed, which was the objective reason for the lack of effect of the agliadin diet in monotherapy (Fig. 3)

Correction of concomitant diseases of the gastrointestinal tract revealed during the study (prescribing enzyme preparations in adequate doses, lactose-free diet in combination with prescribing lactase preparations and sanitation of the small intestine with the prescription of rifaximin in standard doses), made it possible to achieve complete clinical remission within one month of treatment.

So, as a result of our study, we investigated the causes of persistence of clinical symptoms in 41 celiac patients who had been on a gluten-free diet for 6 months. The main reason for the lack of effectiveness of treatment is the violation of a gluten-free diet, identified in $63.4 \%$ of the examined. Revision of food intake and elimination of hidden gluten sources from the diet of celiac disease patients made it possible to achieve complete serological remission (normalization of the titers of celiac diseasespecific antibodies) in all patients, however, complete clinical remission was achieved only in $34.6 \%$. As a result, we drew conclusions about the existence of other causes of incomplete remission of celiac disease, most likely associated with concomitant diseases of the digestive tract.

Using modern carbon and hydrogen breath tests (C13-triglyceride for the diagnosis of EPI, lactose for detecting lactase deficiency, and the D-xylose test used for diagnosing SIBR), a further analysis of the causes of persistence of clinical symptoms in patients strictly adhering to the requirements of a gluten-free diet was carried out. As a result, it was found that, in addition to the violation of the diet, the reasons for the lack of complete remission in patients with celiac disease are exocrine pancreatic insufficiency (19\%), bacterial overgrowth syndrome in the small intestine (16\%), lactase deficiency (47\%) and the combination of EPI with SIBR.

\section{CONCLUSIONS}

The inclusion of breath tests (C13-triglyceride, hydrogen with lactose and D-xylose) in a comprehensive examination of celiac disease patients can significantly improve the results of treatment and shorten the onset of clinical remission.

\section{REFERENCES}

1. Rostom A., Murray J.A., Kagnoff M.F. American gastroenterological Association (AGA) Institute technical review on the diagnosis and management of celiac disease. Gastroenterology. 2006 Dec; 131(6): 1981-2002. DOI: https://doi.org/10.1053/j. gastro.2006.10.004

2. Perederiy O.V. Respiratory tests in gastroenterology. Laboratory diagnostics. 1998; 3: 48-50. [in Russian].

3. Chichula Yu.V. [Comparative evaluation of diagnostic methods for determining exocrine insufficiency of the pancreas]. Author's ref. dissertation: 14.01.36; IvanoFrankivsk Medical University. Ivano-Frankivsk, 2005. [in Ukrainian]

4. Dudar L.V., Chernyavs'kiy V.V., Mihneva N.N. [Correction of antitoxic liver function at chronic diffuse liver disorders in the out-patient conditions]. Modern gastroenterology. 2009; 4 (48): 66-8. [in Russian]. URL: http://www.vitapol.com.ua/user_files/pdfs/gast ro/530694878204793_17092009154053.pdf

5. Tkach S.M., Kozhevnikov A.N., Perederiy V.G. 13C-octanoe breath test in the diagnosis of functional dyspepsia and evaluation of the effectiveness of treatment with motilium. Modern gastroenterology. 2002; 1 (7): 16-8. [in Russian].

6. Perederiy V.G., Tkach S.M., Sizenko A.K., Shvets O.V. [Clinical application of hydrogen breath tests in gastroenterology]. Modern gastroenterology. 2010; 4 (54): 26-33. [in Russian]. URL: https://nmuofficial. $\mathrm{com} /$ files/kaf15/books/vodorodnii-dihatelnie-testi.pdf

7. Tursi A., Brandimante G., Gioretti G.M. H2-breath tests for the diagnosis of celiac disease. Am. J. Gastroenterol. 2002; 97 (10): 2679-80. DOI: 10.1111/j.15720241.2002.06055.x URL: https://journals.lww.com/ ajg/Citation/2002/10000/H2_Breath_Tests_for_The Diagnosis_of_Celiac.45.aspx

8. Keller J., Layer P. Intestinal function tests. Praxis (Bern 1994); 2005 Sep 14; 94(37):1433-8. [in German]. DOI: https://doi.org/10.1024/0369-8394.94.37.1433

9. Di Stefano M., Miceli E., Missanelli A. Malservisi S., Strocchi A., Corazza G.R. Fermentation of endogenous substrates in responsible for increased fasting breath hydrogen levels in celiac disease. J.Clin.Med. 2004 Mar; 143(3): 163-8. DOI: https://doi.org/10.1016/j. lab.2003.11.006

10. Casellas F., Sardi J., de Torres I., Malagelada J.R. Hyrdogen breath test with d-xylose for celiac disease screening is as useful in the elderly as in the other age groups. Dig. Dis.Sci. 2001 Oct; 46(10): 2201-5. DOI: https://doi.org/10.1023/a:1011967016189

11. Castellas F., de Torres I., Malagelada J.R. Improved screening for intestinal villous atrophy by D-xylose breath test. Dig. Dis. Sci. 2000 Jan; 45(1): 18-22. https://doi.org/10.1023/a:1005488705869

12. Murphy M.S., Sood M., Johnson T. Use the lactose H2-breath test to monitor mucosal healing in celiac disease. Acta Paediatr. 2002; 91(2):141-4. https://doi. org/10.1080/080352502317285117

13. Tursi A., Brandimarte G., Gioretti G.M. Sorbitol H2test versusu anti-endomysiom antibodies to assess histological recovery after gluten-free diet in coeliac disease. Dig. Liver Dis. 2002 Dec; 34(12): 846-50. https://doi.org/10.1016/s1590-8658(02)80254-7

14. Tursi A., Brandimarte G., Gioretti G.M., Inofchingolo C.D. Effectiveness sorbitol H2-breath test in detection histological damage among relatives of coeliacs. Scand. J. Gastroenterol. 2003 Jul; 38(7): 727-31. https://doi. org/10.1080/00365520310003697

15. Parfenov A.I. Enterology. M.: Triada-X. 2002. 744 p. [in Russian]. URL:

https://www.booksmed.com/gastroenterologiya/2320yenterologiya-parfenov.html

16. Lorie N.Yu., Petrakov A.V., Parfenov A.I. Hydrogen test: diagnostic capabilities for intestinal diseases. Clinical medicine. 1990; 9: 87-90. [in Russian]. 
17. Loginov A.S., Lorie N.Yu., Parfenov A.I. Diagnostic capabilities of hydrogen determination in exhaled air a new functional test for bowel diseases. Therapeutic archive. 1991; 2: 74-6. [in Russian].

18. Ambrecht U., Stockbrugger R.W. Anwendundsmoglichkeiten und Grenzen des H2-atemtest in der gastroenterologischen. Diagnostik. Z. Gastroent. 1989; 7(27): 361-95

Конфлікт інтересів: відсутній Conflicts of interest: authors have no conflict of interest to declare. Надійшла до редакції / Received: 02.09.2020 Падийла до редакціi/ Recelved. 02.09.2020

Прийнято по друку / Accepted. 21.09 .2020

\section{СУЧАСНІ МОЖЛИВОСТІ ПОЛІПШЕННЯ ЕФЕКТИВНОСТІ ЛІКУВАННЯ ЦЕЛІАКІЇ}

Губська О.Ю., Чичула Ю.В., Сизенко Г.К., Купчик Л.М.

Начіональний медичний університет імені О.О. Богомольия, Київ, Украӥна gubskao@gmail.com

Актуальність. Хоча монотерапія безглютеновою дієтою (БГД) при целіакії і $є$ високоефективною, але все ж таки не у всіх випадках дозволяє досягти повної ремісії захворювання. Тому актуальним є додаткове комплексне обстеження хворих з метою призначення обгрунтованої терапії.

Мета: вивчити причини персистенції клінічної симптоматики у хворих на целіакію, що знаходяться на безглютеновій дієті 6 місяців

Матеріали та методи. Досліджені хворі на целіакію (n=41), що знаходилися на безглютеновій дієті 6 місяців. Середній вік - 35,42 $\pm 0,45$ років. Група $1(\mathrm{n}=17)$ - пацієнти, які суб' єктивно відзначали позитивну динаміку лікування і достовірне поліпшення загального стану, але без повної клінічної ремісії. Група 2 (n=24) - пацієнти з незадовільними результатами лікування, відсутністю клінічного ефекту від лікування або слабкою позитивною динамікою на тлі БГД. Дослідження включало два етапи: 1) оцінка комплайєнса пацієнтів та їх раціону харчування (за допомогою аналізу харчових шоденників) з метою виявлення порушення безглютенової дісти, як основної причини персистенції клінічної симптоматики; 2) виявлення інших причин персистенції симптоматики: зовнішньосекреторної недостатності підшлункової залози (ЗНПЖ), лактазної недостатності (ЛН) і синдрому надлишкового бактеріального росту (СНБР). 3 метою діагностики ЗНПЖ виконувався С13-тригліцеридний дихальний тест (аналізатор IRIS). Для діагностики ЛН і СНБР в тонкій кишці застосовували водневі дихальні тести (аналізатор Місго H2-meter) - тест з лактозою і D-ксилозою, відповідно. Також у всіх пацієнтів визначали титр антитіл до тканинної трансглутамінази (ТTГ), до дезамінірованих пептидів гліадину (ДПГ), розраховували їх співвідношення ДПГ / ТТГ.

Результати. Основною причиною недостатньої ефективності лікування є порушення безглютенової дієти, виявлене у 63,4\% обстежених (не в повному обсязі сформований кашкоподібний стілець, поліфекалія, стеаторея; рецидивуюча біль в животі, здуття, флатуленція). Перегляд споживаних продуктів харчування і виключення з раціону хворих на целіакію джерел прихованого глютену дозволив досягти повної серологічної ремісії (нормалізації титрів специфічних для целіакії антитіл) у всіх пацієнтів, однак повна клінічна ремісія була досягнута тільки у тільки 34,6\%. Тому зроблені висновки про існування інших причин неповної ремісії целіакії, пов'язаних із супутніми захворюваннями органів травного каналу. За допомогою вуглецевого і водневих дихальних тестів встановлено, що, крім порушення дієти, причинами відсутності повної ремісії у хворих на целіакію є ЗНПЖ (19\%), СНБР в тонкій кишці (16\%), ЛН (47\%) і комбінація ЗНПЖ з СНБР.

Висновок. Включення в комплексне обстеження хворих на целіакію дихальних тестів (С13-тригліцеридного, водневого 3 лактозою і D-ксилозою) може значно поліпшити результати лікування і скоротити терміни настання клінічної ремісії.

Ключові слова: целіакія, безглютенова дієта, дихальні тести, С13-тригліцеридний, водневий з лактозою і D-ксилозою

\section{СОВРЕМЕННЫЕ ВОЗМОЖНОСТИ ПОВЫШЕНИЯ ЭФФЕКТИВНОСТИ ЛЕЧЕНИЯ ЦЕЛИАКИИ}

Губская Е.Ю., Чичула Ю.В., Сизенко А.К., Купчик Л.М.

Национальный медицинский университет имени А.А. Богомольца, Киев, Украина gubskao@gmail.com

Актуальность. Хотя монотерапия безглютеновой диетой (БГД) при целиакии и является высокоэффективной, но всё же не во всех случаях позволяет достичь полной ремиссии заболевания. Поэтому актуальным является дополнительное комплексное обследование больных с целью назначения обоснованной терапии.

Цель: изучить причины персистенции клинической симптоматики у больных целиакией, находящихся на безглютеновой диете 6 месяцев.

Материалы и методы. Исследованы больные целиакией (n=41), находившиеся на безглютеновой диете 6 месяцев. Средний возраст $-35,42 \pm 0,45$ лет. Группа $1(\mathrm{n}=17)$ - пациенты, субъективно отмечавшие положительую динамику лечения и с достоверным улучшением общего состояния, но без полной клинической ремиссии. Группа 2 (n=24) - пациенты с неудовлетворительными результатами лечения, отсутствием клинического эффекта от лечения или слабой позитивной динамикой на фоне БГд. Исследование включало два этапа: 1) оценка комплайенса пациентов и их рациона питания (посредством анализа пищевых дневников) с целью выявления нарушения безглютеновой диеты, как основной причины персистенции клинической симптоматики; 2) выявление других причин персистенции симптоматики: внешнесекреторной недостаточности поджелудочной железы (ВНПЖ), лактазной недостаточности (ЛН) и синдрома избыточного бактериального роста (СИБР). С целью диагностики ВНПЖ выполнялся С13-триглицеридный дыхательный тест (анализатор IRIS). Для диагностики ЛН и СИРБ в тонкой кишке применяли водородные дыхательные тесты (анализатор Місго Н2meter) - тест с лактозой и D-ксилозой, соответственно. Также у всех пациентов определяли титр антител к тканевой трансглутаминазе (ТТГ), к дезаминированным пептидам глиадина (ДПГ), рассчитывали их соотношение ДПГ/ТТГ.

Результаты. Основной причиной недостаточной эффективности лечения является нарушение безглютеновой диеты, выявленное у 63,4\% обследованных (не полностью сформированный кашицеобразный стул, полифекалия, стеаторея; рецидивирующая боль в животе, вздутие, флатуленция). Пересмотр потребляемых продуктов питания и исключение из рациона больных целиакией источников скрытого глютена позволил достичь полной серологической ремиссии (нормализации титров специфичных для целиакии антител) у всех пациентов, однако полная клиническая ремиссия была достигнута только у только 34,6\%. Поэтому сделаны выводы о существовании других причин неполной ремиссии целиакии, связанных с сопутствующими заболеваниями органов пищеварительного канала. При помощи углеродного и водородных дыхательных тестов установлено, что, помимо нарушения диеты, причинами отсутствия полной ремиссии у больных целиакией являются ВНПЖ (19\%), СИБР в тонкой кишке (16\%), ЛН (47\%) и комбинация ВНПЖ с СИБР.

Вывод. Включение в комплексное обследование больных целиакией дыхательных тестов (С13-триглицеридного, водородного с лактозой и D-ксилозой) может значительно улучшить результаты лечения и сократить сроки наступления клинической ремиссии. 